\title{
Human and bacterial DNA polymerases discriminate against 8-oxo-2'-deoxyadenosine- 5'-triphosphate
}

\author{
I. R. Grin, S. V. Vasilyeva, A. P. Dovgerd, V. N. Silnikov, D. O. Zharkov
}

Novosibirsk Institute of Chemical Biology and Fundamental Medicine, Siberian Branch of the Russian Academy of Sciences 8, Akademika Lavrentieva Ave., Novosibirsk, Russian Federation, 630090

dzharkov@niboch.nsc.ru

\begin{abstract}
Aim. 8-Oxoadenine is an abundant DNA lesion associated with cancer and neurodegeneration. It may appear through direct oxidation of adenine in DNA or by incorporation from the oxidized dNTP pool. Methods. We developed an efficient method of synthesizing 8-oxo-2'-deoxyadenosine-5'-triphosphate and studied its incorporation by various DNA polymerases. Results. oA was weakly misincorporated opposite guanine by the DNA polymerase I Klenow fragment. Limited incorporation of oA was observed opposite guanine and adenine with DNA polymerase $\alpha$, and opposite adenine, thymine and guanine with DNA polymerase $\beta$. Conclusions. Adenine oxidation in DNA may outweigh damage to dATP as a source of genomic oA.
\end{abstract}

Keywords: mutagenesis, DNA damage, oxidative stress, 8-oxoadenine, DNA polymerases.

Introduction. 8-Oxoadenine (oA) is a major product of adenine damage by ionizing radiation and metabolically generated free radicals [1]. The levels of oA in DNA are similar to those of other ubiquitous lesion, 8-oxoguanine [2], and increase in tumors [3]. When present in DNA, $\mathrm{oA}$ is weakly mutagenic [4]. Intriguingly, human cells possess two enzymes, OGG1 and NEIL1, that remove oA from oA:C pairs but not from oA:T [5].

oA can appear in DNA in two ways. A in DNA may be directly oxidized, producing oA:T pairs. Alternatively, A in dATP may be damaged, and the resulting odATP could be used by DNA polymerases to incorporate oA opposite $\mathrm{T}$ or another base. Human cells express specific odATPases [6], underscoring the importance of this damaged dNTP. Whereas a wealth of data exists for 8-oxoguanine and its dNTP [7], little is known about the utilization of odATP by DNA polymerases. It has been reported that, with $\mathrm{T}$ in the template, odATP is $\sim 800$-fold less efficient than dATP as a substrate for the exonuclease-deficient Klenow fragment ( $\mathrm{KF}$ exo $^{-}$)

(C) Institute of Molecular Biology and Genetics, NAS of Ukraine, 2012
[8]. We describe an efficient synthesis of odATP and an analysis of its use by DNA polymerases.

Materials and methods. Synthesis of odATP. 8oxo-2'-deoxyadenosine (Fig. 1, 2) was synthesized from 8-bromo-2'-deoxyadenosine 1 («ChemGenes», USA) by treatment with $3 \mathrm{M}$ equiv. of 2-mercaptoethanol and $10 \mathrm{M}$ equiv. of triethylamine in water [9]. The product $(90 \%$ yield) was purified by chromatography on $\mathrm{C}_{18}$ silica gel column in water-acetonitrile. Compound $\mathbf{2}$ was identified by comparison of ${ }^{1} \mathrm{H}$ NMR and MS spectra with the literature data [9]. 5'-Triphosphate of $\mathbf{2}$ was synthesized by the Ludwig method [10] with modifications. The solution of 2 (100 mg, $0.374 \mathrm{mmol}$ ) in anhydrous trimethyl phosphate and tributylamine $(267 \mu 1,1.122 \mathrm{mmol})$ was chilled on ice, and freshly distilled phosphorous oxychloride $(77 \mu 1,0.823 \mathrm{mmol})$ was added. The mixture was stirred for $20 \mathrm{~min}$ and mixed into $0.5 \mathrm{M}$ bis(tetra- $n$-butylammonium) pyrophosphate in acetonitrile $(2.24 \mathrm{ml}$, $1.122 \mathrm{mmol})$ and tributylamine $(0.267 \mathrm{ml}, 1 \mathrm{mmol})$ with vigorous stirring. After stirring for $30 \mathrm{~min}$ at room temperature, $30 \mathrm{ml}$ of $1 \mathrm{M}$ triethylammonium bicarbonate ( $\mathrm{pH} 7.5)$ was added. After $2 \mathrm{~h}$, the reaction mixture 

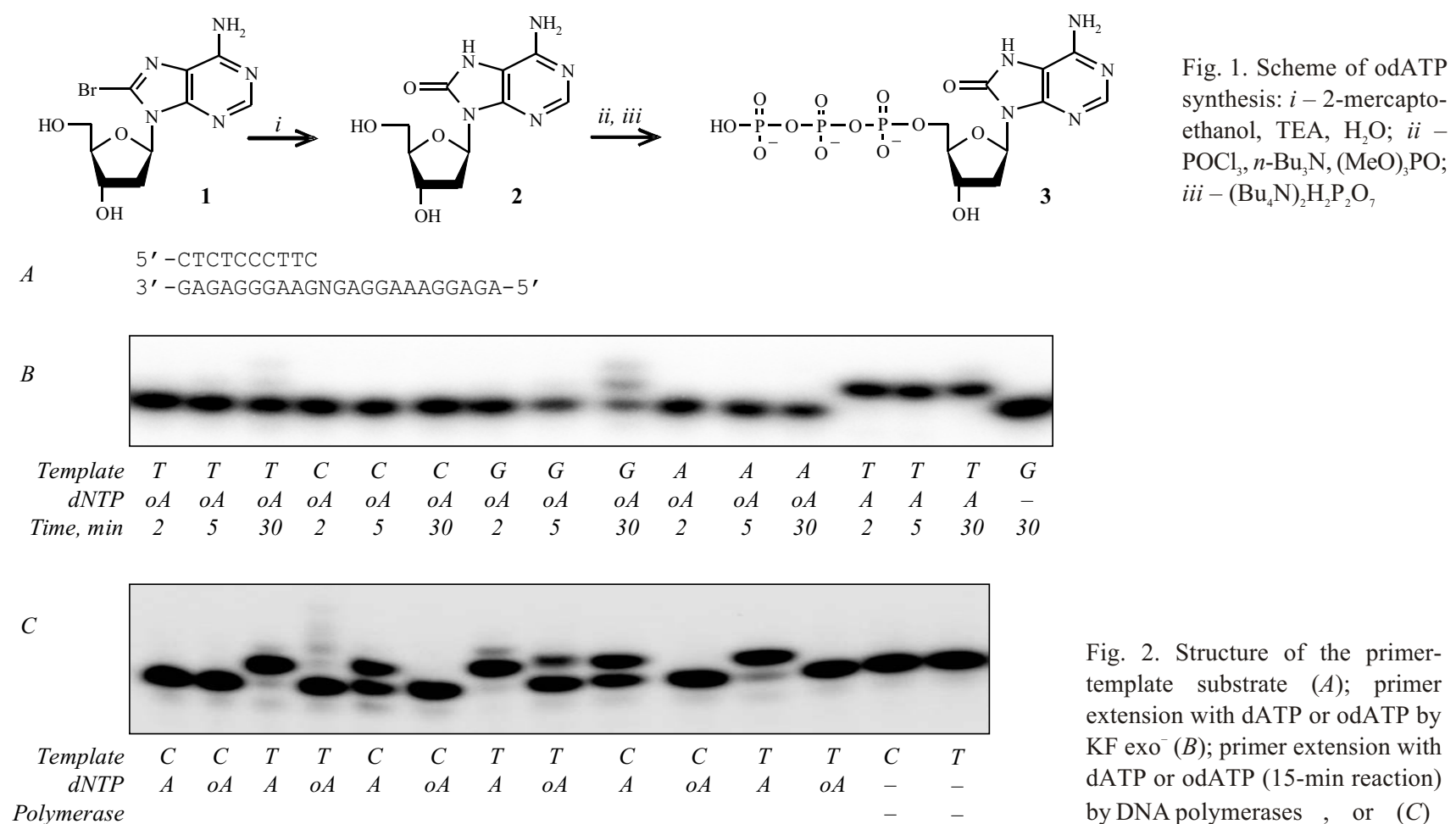

Fig. 2. Structure of the primertemplate substrate $(A)$; primer extension with dATP or odATP by $\mathrm{KF}$ exo $^{-}(B)$; primer extension with dATP or odATP (15-min reaction) by DNA polymerases $\alpha, \beta$ or $\lambda(C)$

was dried. The product 3 was purified by anion exchange chromatography on a Polysil SA $15 \mu \mathrm{m}$ column using a linear $\mathrm{NaCl}$ gradient $(0 \rightarrow 1 \mathrm{M})$ in $0.1 \%$ aqueous $\mathrm{CH}_{3} \mathrm{COOH}$, and then on DEAE-Sephadex A-25 (40$120 \mu \mathrm{m})$ using a linear $\mathrm{NH}_{4} \mathrm{HCO}_{3}$ gradient $(0 \rightarrow 1 \mathrm{M})$ in water. Appropriate fractions were pooled and dried several times with aqueous ethanol. Li-odATP was precipitated by 10 vol. $6 \% \mathrm{LiClO}_{4}$ in acetone.

Characterization of the product: ${ }^{1} \mathrm{H}$ NMR $\left(\mathrm{D}_{2} \mathrm{O}\right), \delta$ (ppm): 8.06 (s, 1H, H2); 6.39 (app. t, $1 \mathrm{H}, \mathrm{H} 1$ ', J 7); 4.22-4.06 (m, 2 H, H3', 4'); 3.50-3.42 (m, 2 H, H5'); 3.20-2.24 (m, $\left.2 \mathrm{H}, \mathrm{H} 2{ }^{\prime}\right) ;{ }^{31} \mathrm{P}$ NMR $\left(\mathrm{D}_{2} \mathrm{O}\right), \delta(\mathrm{ppm})$ : $-21.79\left(\mathrm{~m}, 1 \mathrm{P}, \mathrm{P}_{\beta}\right) ;-10.40\left(\mathrm{~m}, 1 \mathrm{P}, \mathrm{P}_{\alpha}\right) ;-8.98(\mathrm{~m}, 1 \mathrm{P}$, $\mathrm{P}_{\gamma}$ ). LC/MSD XCT Ion Trap («Agilent Technologies», USA), $[\mathrm{M}+\mathrm{H}]^{+}$: expected $m / z 532.5\left(4-\mathrm{Li}^{+}\right)$, found $m / z$ 532.03 .

Oligonucleotides and enzymes. Oligonucleotides (Figs 2 and 3) were made by «Biosan» (Russia) and purified by electrophoresis in $20 \%$ polyacrylamide gel (PAGE) with $8 \mathrm{M}$ urea. The primers were labeled using $\left[\gamma-{ }^{32} \mathrm{P}\right]$ ATP and T4 polynucleotide kinase («Biosan»). KF exo ${ }^{-}$was from «New England Biolabs» (USA); mouse embryonic fibroblast extracts, calf thymus DNA polymerase $\alpha$ and recombinant human DNA polymerases $\beta$ and $\lambda$ were a gift from Dr. Olga Lavrik (ICBFM).
DNA polymerase reactions. The reaction mixtures $(20 \mu \mathrm{l})$ included $100 \mathrm{nM}$ primer-template, $0.5 \mathrm{mM}$ dNTP and: $50 \mathrm{mM}$ Tris- $\mathrm{HCl}, \mathrm{pH} 7.5,5 \mathrm{mM} \mathrm{MgCl}, 30 \mathrm{mM}$ $\mathrm{KCl}, 0.1 \mathrm{mM}$ DTT, $0.25 \mathrm{mg} / \mathrm{ml} \mathrm{BSA}$, and $2.5 \mathrm{U}$ of $\mathrm{KF}$ exo'; or $50 \mathrm{mM}$ Tris-HCl, pH 7.5, $5 \mathrm{mM} \mathrm{MgCl}_{2}, 1 \mathrm{mM}$ DTT, and $0.5 \mu \mathrm{M}$ Pol $\alpha$; or $50 \mathrm{mM}$ Tris-HCl, $\mathrm{pH}$ 8.0, $25 \mathrm{mM} \mathrm{KCl}, 10 \mathrm{mM} \mathrm{MgCl}, 1 \mathrm{mM}$ DTT, and $0.5 \mu \mathrm{M}$ Pol $\beta$; or $50 \mathrm{mM}$ Tris- $\mathrm{HCl}, \mathrm{pH} 8.0,0.5 \mathrm{mM} \mathrm{MnCl}_{2}$, $0.5 \mathrm{mM}$ DTT, and $0.5 \mu \mathrm{M}$ Pol $\lambda$; or $50 \mathrm{mM}$ Tris- $\mathrm{HCl}$, $\mathrm{pH} 8.0,10 \mathrm{mM} \mathrm{MgCl}{ }_{2}, 1 \mathrm{mM}$ DTT, and $20 \mu \mathrm{g}$ of cell extract. After $2-30 \mathrm{~min}$ at $25^{\circ} \mathrm{C}$ the products were resolved by PAGE and visualized by phosphorimaging (Molecular Imager FX, «Bio-Rad», USA).

Results and discussion. The yield of odATP was $33 \mathrm{mg}$ ( $45 \%$ of the starting material). odATP was used for primer extension by $\mathrm{KF}$ exo ${ }^{-}$in a binary primertemplate system (Fig. 2, A). As shown in Fig. 2, $B$, little if any incorporation was observed opposite $\mathrm{T}$, whereas the primer was quickly extended when dATP was present. This observation confirms the previous report of poor substrate properties of odATP for KF exo [8]. No incorporation of oA occurred opposite A or C. However, with $\mathrm{G}$ in the template, the primer was elongated by one and two nucleotides after $30 \mathrm{~min}$. Incorporation of two oA residues is consistent with the presence of ano- 


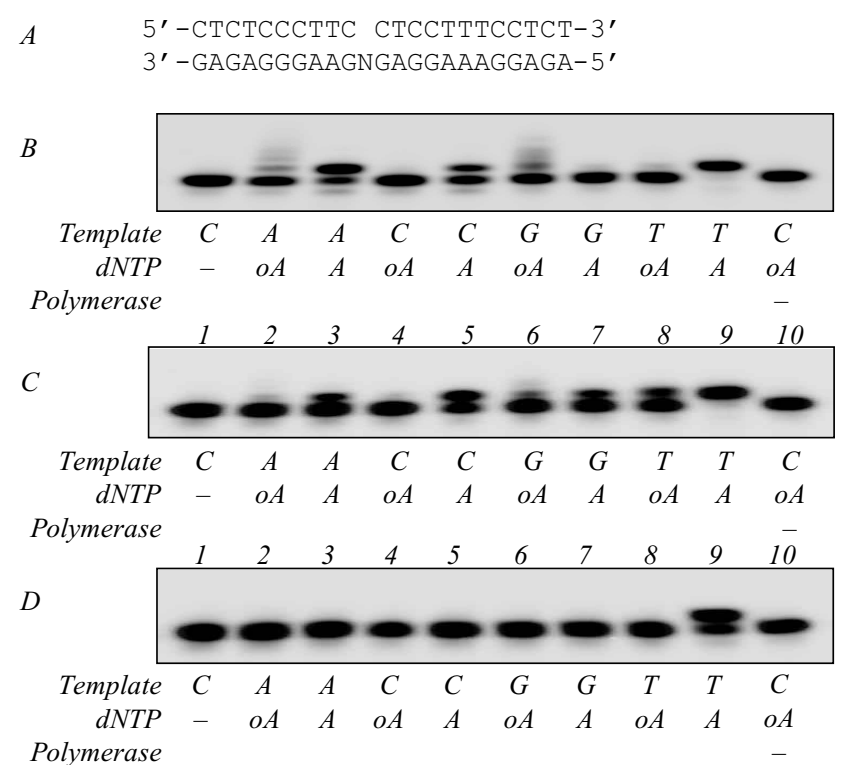

Fig. 3. Structure of the gapped substrate $(A)$; primer extension with dATP or odATP (15-min reaction) by DNA polymerases $\alpha(B), \beta(C)$, or $\lambda(D)$ by Pol $\alpha$, Pol $\beta$, or Pol $\lambda$. Interestingly, taken in a large excess, Pol $\beta$ and Pol $\lambda$ incorporated A opposite C, consistent with their lower fidelity in comparison with Pol $\alpha[12]$.

Binary primer-template is suboptimal for Pol $\beta$ and Pol $\lambda$, which prefer substrates with a short gap [13]. Therefore, we studied the behavior of $\operatorname{Pol} \alpha, \operatorname{Pol} \beta$, and Pol $\lambda$ when presented with odATP and a gapped substrate consisting of a template, a primer, and a downstream strand (Fig. 3, A). All polymerases efficiently incorporated A opposite T (Fig. 3, $B-D$ ). Pol $\alpha$ misincorporated A opposite A and, less efficiently, opposite C. In contrast, no incorporation of oA opposite $\mathrm{C}$ or $\mathrm{T}$ was observed. When $\mathrm{A}$ or $\mathrm{G}$ were in the template, oA was weakly incorporated with some extension to the +2 position, similar to that observed with $\mathrm{KF}$ and the binary primer-template. Pol $\beta$ misincorporated A opposite $\mathrm{A}, \mathrm{C}$, and $\mathrm{G}$, whereas oA was incorporated much wor-

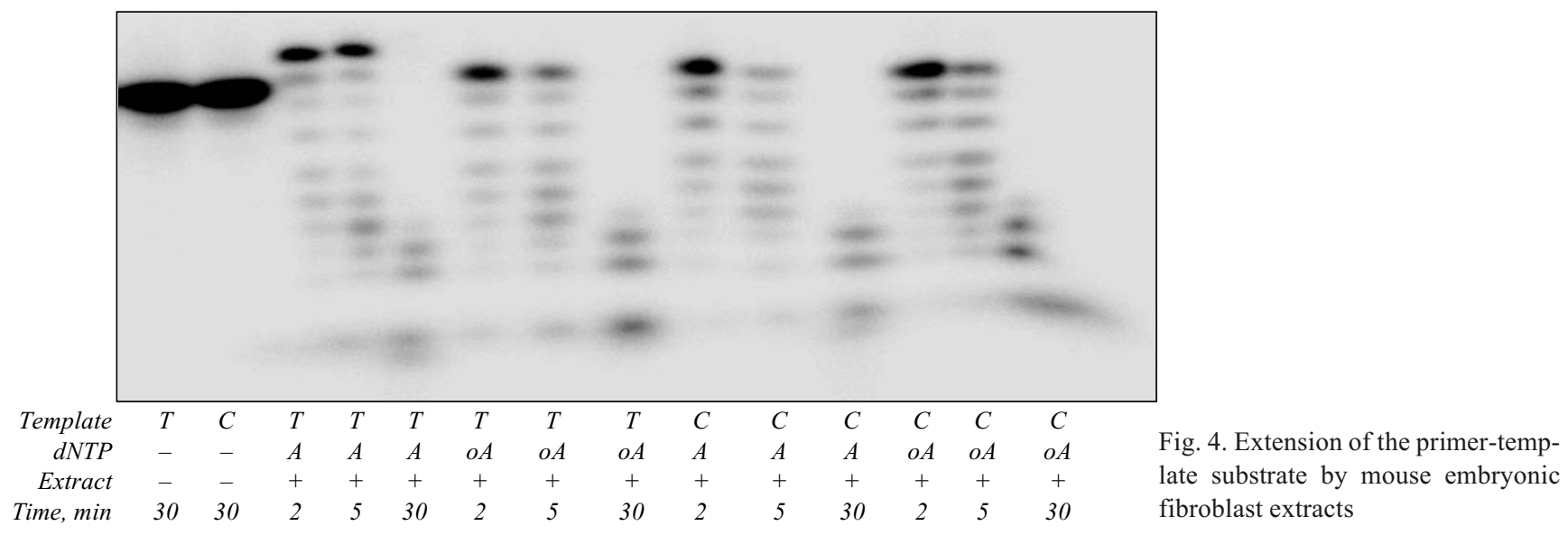

ther $\mathrm{G}$ in the +2 position (Fig. 2, A). The oA $(s y n)$ : :G(anti) Hoogsteen pair is stable [11], permitting oA incorporation opposite $\mathrm{G}$.

$\mathrm{KF}$ is a member of DNA polymerase Family A, whereas most human DNA polymerases belong to other families. To assess the mutagenic potential of odATP in human cells, we performed the reaction using the highfidelity Pol $\alpha$ (Family B), and two Family X enzymes, Pol $\beta$ and Pol $\lambda$, normally participating in DNA repair [12]. With the binary primer-template, all three enzymes efficiently incorporated A opposite T (Fig. 2, C). However, only Pol $\beta$ incorporated oA opposite $\mathrm{T}$ to any extent. We observed no incorporation of oA opposite $\mathrm{C}$ se, with the order of the template preference $\mathrm{T}>\mathrm{G}>\mathrm{A}$. Pol $\lambda$ catalyzed only normal incorporation of A opposite $\mathrm{T}$, did not form mismatches with $\mathrm{A}$ and did not incorporate oA.

Finally, we inquired whether odATP is used by DNA polymerases present in mammalian cell extracts. Whole-cell mouse embryonic fibroblast extracts efficiently incorporated A opposite T (Fig. 4). However, no incorporation of oA was evident. It is still possible that such incorporation is not observed due to the primer degradation by nucleases.

It is instructive to compare the situation when oA is present in dNTP and in DNA. KF bypasses template oA 
in an error-free manner when all four dNTPs are available [4]. On the contrary, when this lesion is present as odATP, it is poorly incorporated by KF and tends to be misincorporated opposite G. Small amounts of G or A are incorporated opposite oA by KF, Pol $\alpha$ and Pol $\beta$ when only dGTP or dATP is present [4]. In our experiments, a small degree of misincorporation of oA by Pol $\alpha$ and Pol $\beta$ is also observed opposite A and G, suggesting that the acceptance of oA may require Hoogsteentype pairing.

Conclusions. Our data hint that oxidative damage of the dATP pool and incorporation of oA may be less important than direct oxidation of A in DNA as a source of genomic oA. However, this does not mean that odATP has no effect in vivo. The proposed synthetic pathway to oxodATP will permit a more detailed investigation of its properties.

Acknowledgements. This work was supported by RAS Presidium (Molecular and Cellular Biology, N 6.14), SB RAS (N 88), RFBR (11-04-00807-a), and President's Grant MK-2703.2011.4 to I. G.

\section{І. Р. Грін, С. В. Васильєва, А. П. Довгерд, В. Н. Сильніков, Д. О. Жарков}

Дискримінація 8-оксо-2'-дезоксиаденозин-5'-трифосфату ДНК-полімеразами бактерій і людини

\section{Резюме}

Мета. 8-оксоаденін - розповсюджена пошкоджена основа, асоиійована з онкологічними і нейродегенеративними захворюваннями. Воно може виникати внаслідок безпосереднього окиснення аденіну в ДНК або при вбудовуванні окисненого dNTP. Методи. Розроблено ефективний спосіб синтезу 8-оксо-2'-дезоксиаденозин-5'-трифосфату і вивчено його включення в ДНК різними ДНК- полімеразами. Результати. Фрагмент Кленова ДНК-полімерази I з невисокою ефективністю включав оА навпроти гуаніну. Для ДНК-полімерази а спостерігалося обмежене включення оА навпроти гуаніну і аденіну, а для ДНК-полімерази $\beta$ - навпроти аденіну, тиміну і гуаніну. Висновки. Як джерело оА в геномі окиснення аденіну в ДНК може мати більше значення, ніж окиснення

Ключові слова: мутагенез, пошкодження ДНК, оксидативний стрес, 8-оксоаденін, ДНК-полімерази.

И. Р. Грин, С. В, Васильева, А. П. Довгерд, В. Н. Сильников, Д. О. Жарков

Дискриминация 8-оксо-2'-дезоксиаденозин-5'-трифосфата ДНК-полимеразами бактерий и человека

Резюме

Цель. 8-оксоаденин - распространенное поврежденное основание, ассоциированное с онкологическими и нейродегенеративны- ми заболеваниями. Оно может возникать вследствие непосредственного окисления аденина в ДНК или при включении окисленного dNTP. Методы. Разработан эффективный способ синтеза 8-оксо-2'-дезоксиаденозин-5'-трифосфата и изучено его включение в ДНК разныли ДНК-полимеразами. Результаты. Фрагмент Кленова ДНК-полимеразы I с невысокой эффективностью включал оА напротив гуанина. Для ДНК-полимеразы $\alpha$ наблюдалось ограниченное включение оА напротив гуанина и аденина, а для ДНК-полимеразы $\beta$-напротив аденина, тимина и гуанина. Выводы. Как источник оА в геноме окисление аденина в ДНК может иметь больиее значение, чем окисление dАТР.

Ключевые слова: мутагенез, повреждение ДНК, оксидативный стресс, 8-оксоаденин, ДНК полимеразы.

\section{REFERENCES}

1. Von Sonntag C. Free-radical-induced DNA damage and its repair: A chemical perspective.-Heidelberg: Springer, 2006.$523 \mathrm{p}$.

2. Gajewski E., Rao G., Nackerdien Z., Dizdaroglu M. Modification of DNA bases in mammalian chromatin by radiation-generated free radicals // Biochemistry.-1990.-29, N 34.-P. 7876-7882.

3. Jaruga P., Zastawny T. H., Skokowski J., Dizdaroglu M., Olinski $R$. Oxidative DNA base damage and antioxidant enzyme activities in human lung cancer // FEBS Lett.-1994.-341, N 1.-P. 59-64.

4. Shibutani S., Bodepudi V., Johnson F., Grollman A. P. Translesional synthesis on DNA templates containing 8-oxo-7,8-dihydrodeoxyadenosine// Biochemistry.-1993.-32, N 17.-P. 4615-4621.

5. Grin I. R., Dianov G. L., Zharkov D. O. The role of mammalian NEIL1 protein in the repair of 8-oxo-7,8-dihydroadenine in DNA // FEBS Lett.-2010.-584, N 8.-P. 1553-1557.

6. Fujikawa K., Kamiya H., Yakushiji H., Fujii Y., Nakabeppu Y., Kasai $H$. The oxidized forms of dATP are substrates for the human MutT homologue, the hMTH1 protein // J. Biol. Chem.1999.-274, N 26.-P. 18201-18205.

7. Nakabeppu Y., Sakumi K., Sakamoto K., Tsuchimoto D., Tsuzuki T., Nakatsu $Y$. Mutagenesis and carcinogenesis caused by the oxidation of nucleic acids // Biol. Chem.-2006.-387, N 4.- P. 373379.

8. Purmal A. A., Kow Y. W., Wallace S. S. 5-Hydroxypyrimidine deoxynucleoside triphosphates are more efficiently incorporated into DNA by exonuclease-free Klenow fragment than 8oxopurine deoxynucleoside triphosphates // Nucleic Acids Res.1994.-22, N 19.-P. 3930-3935.

9. Chatgilialoglu C., Navacchia M. L., Postigo A. A facile one-pot synthesis of 8-oxo-7,8-dihydro-(2'-deoxy)adenosine in water // Tetrahedron Lett.-2006.-47, N 5.-P. 711-714.

10. Ludwig J. A new route to nucleoside 5'-triphosphates // Acta Biochim. Biophys. Acad. Sci. Hung.-1981.-16, N 3-4.-P. 131-133.

11. Leonard G. A., Guy A., Brown T., Teoule R., Hunter W. N. Conformation of guanine-8-oxoadenine base pairs in the crystal structure of d(CGCGAATT(O8A)GCG) // Biochemistry.-1992.- 31, N 36.-P. 8415-8420.

12. Showalter A. K., Lamarche B. J., Bakhtina M., Su M. I., Tang K. H., Tsai M. D. Mechanistic comparison of high-fidelity and errorprone DNA polymerases and ligases involved in DNA repair // Chem. Rev.-2006.-106, N 2.-P. 340-360.

13. Beard W. A., Wilson S. H. Structure and mechanism of DNA polymerase beta // Chem. Rev.-2006.-106, N 2.-P. 361-382. 